\title{
Human Resources Accounting: A Suggested Model for Measurement and Valuation
}

\author{
Thomas Arkan*
}

\begin{abstract}
The global transition from manufacturing to service based economies and later to knowledgebased economies implies a greater focus on employee resources because of global skill shortages, and more complex internal company knowledge that might be lost should an employee leave the organization. Acknowledged by economists as the most important resource because it controls and directs the other resources, people within an organization directly influence the success or failure of that organization. As a result of its significance, a special interest in Human Resource Accounting has developed where many models and techniques have been proposed for valuing human resources more broadly. Despite robust research there remains much debate as to whether human resource should be included or excluded in the financial statement. Historically, accounting has not recognized human resources as an asset in the statement of financial position, because of a dearth of acceptable metrics applicable to people under employment, and also due to a lack of suitable models for use in attributing a value to a human resource. Clearly, a knowledge gap of this nature raises questions for accounting practices where human capital is the focus. Human resource accounting has the potential to provide an alternative solution helpful to management decision-making especially regarding the adequacy of human resources when viewed within a financial health framework. To date however, there exists a need to further establish a credible platform for human resource accounting, particularly via the achievement of robust qualitative research results. As such this article analyses further the possibility of including human resources within the definition of asset, defines types of expenditure required in financial statements and proposes the types of disclosure necessary for a presentation of human resource assets. Specifically, this article also proposes a valuation model that overcomes the limitations of previous models, and includes calculations suitable for inclusion in the statement of financial position. An added outcome of this article is a more defined concept of Human Resource Accounting as a subset of general accounting, seen within International Financial Reporting Standards (IFRSs) and applicable to the 2015 financial reporting IAS 38 .
\end{abstract}

Keywords: Human resources accounting (HRA), IAS38, the Flamholtz model, and Lev and Schwartz model

\section{Introduction to Human Resources Accounting}

Barcelona could lose Lionel Messi, Luis Suarez or Neymar because of their wage demands, claims club economic vice-president Javier Faus.

While considered critically important by owners and managers, the process of organizing, identifying, measuring, directing and controlling the human resources of an organization remains a difficult task for managers. Previous attempts to find tools and techniques to identify and disclose the real value of human resources as firm assets to the organization have

\footnotetext{
*Thomas Arkan, University of Szczecin, Department of Economics, e-mail: danmarkkbh@yahoo.com.
} 
been problematic, despite the clear dependence of an organization on its human capital for revenue creation, whether through intellectual endeavours or via physical effort. It is widely acknowledged that human resources are key to the success or failure in any firm. Human Resource Accounting (HRA) helps management frame policies for human resources especially where it is necessary to identify measure and disclose data about the people within an organization, where they are recognized as an accounting resource. It involves two areas of measurement: first it measures the cost incurred by an organization to recruit, select, hire, train and develop human assets, and secondly, it involves calculating the economic value of people to the organization... Usually firms who apply HRA concepts in their accounting systems situate this information in a separate section of their annual reports, and provide a detailed account of their human resources. While physical assets such as plants machinery, buildings etc. are necessary for any organization, they are largely static and unproductive and require a decision in order to be initiated. A decision inevitably made by a human, one who performed, or managed some task within the organization. Clearly, the profitability, productivity, solvency and efficiency of any organization depend largely upon the activities of human resources. Reporting on human assets usually includes a profile of human assets, the compensation pattern, training and development events and policies, human asset productivity, human asset value, and the total wealth of the organization.

The concept underpinning the HRA is that the people in a company (the human resources) represent a certain value that can be compared to other resources (Flamholtz et al. 2002). HRA implies accounting for people as human assets where it can be used as a tool to measure human resources and as a management tool (Flamholtz et al. 2002). The concept of considering human beings as an asset is an old phenomenon and it goes back to the labour theory of value where pioneering economists argued on firm value creation via labour,. For example, Paton (1920) casts doubt on the credibility of a balance sheet without the presentation of loyal personnel. In the mid 1990's accounting for people had greatly been improved, leading to the phrase 'our people are our greatest asset'.

The major tenet of HRA is that it involves accounting for the company's management and treats employees as human capital which provides future benefits. For example, expenditures related to human resources are reported as assets on the balance sheet as opposed to the traditional accounting approach which treats costs related to a company's human resources as expenses on the income statement that reduce profit. Traditional accounting also involves sophisticated calculations requiring all manner of estimations, assumptions and variables that need to be factored in. HRA instead focuses on the accounting of costs associated with acquiring personnel along with the programs adopted to enhance personnel efficiency. Traditionally in financial statements it is tagged as human capital or intellectual asset accounting and usually labelled as investments made in the Human Resources of an organization. Human capital refers to a set of knowledge and competence, skills and training, innovation and capabilities, attitudes and skills, learning ability and motivation of the people who form the organization. It is argued that quantifying the value of Human 
Resources helps management to cope up with the changes in its quantum and quality so that equilibrium can be achieved between the required resources and the provided human resources. According to (Ripoll 1994) there are two reasons for including human resources in accounting. Firstly, people are a valuable resource to a firm as long as they perform services that can be quantified. Secondly, the value of a person as a resource depends on how he/she is employed. So management style will also influence the human resource value. Drawing from previous work this paper focuses on HRA as an information system relevant to organizational usefulness, decision- making, valuation and related issues, where 3 main goals are achieved, namely:

- The provision of objective and quantitative data relating to the total cost, total revenues and the value of human resources of the organization,

- Working within a theoretical framework that guides decisions regarding cost effectiveness in the acquisition, development and maintenance of human resources, and

- Encouraging and promoting decision-maker's interest in human resources and considering their perspectives.

\section{Early Development of Human Resource Accounting Concepts}

Early interest in HRA came from several sources, such as the economic theory of human capital, where the first attempt to value human beings in monetary terms was made by Sir William Petty as early as 1691 . Petty was of the opinion that labour was the father of wealth and it must be included in any estimate of national wealth. Further efforts were made by William Far in 1853, followed by Earnest Engle in 1883. Flamhotz et al. (2002), states that some theorists like Scot (1925) spoke about treating people as assets and accounting for their value at the beginning of the twentieth century. However, the most productive period of research of human HRA started at the beginning of the 1960s and was strongly influenced by the disciplines of sociology, industrial psychology and economics (Grojer, Johanson 1997). Research in 1999 by Flamholtz, Pylet and his team at Michigan University generated a chronological history of the development of Human Resources Accounting depicted by five stages as shown in Table 1. Each of these stages is discussed in more detail on the next page.

The first stage. The interest in human resources accounting began in this period. A number of theorists such as Scott (1925) and Peyton (1962) supported the idea of considering human resources as its asset and valuation. Also, organizational psychologists like Likert believed that human resources were considered to be in default as the valuable resources of organization. Hermanson (1964-1986) presented a model for human resource valuation to the financial reporting of an external organization. He identified that human resource accounting was primarily used as a managerial tool, instead of as a way to value people as assets. 
Table 1

Historical development of HRA

\begin{tabular}{ll}
\hline $\begin{array}{l}\text { Stage 1 } \\
\text { 1960-1966 }\end{array}$ & $\begin{array}{l}\text { The origin of Human Resources Accounting with theories, representing inference of the basic } \\
\text { concepts (primary) of human resource accounting. }\end{array}$ \\
\hline $\begin{array}{l}\text { Stage } 2 \\
\text { 1967-1970 }\end{array}$ & The first basic academic formulation of some measuring models \\
\hline $\begin{array}{l}\text { Stage } 3 \\
1971-1977\end{array}$ & Rapid increase in interest levels in Human Resources Accounting \\
\hline $\begin{array}{l}\text { Stage } 4 \\
1978-1980\end{array}$ & $\begin{array}{l}\text { Static academic interest level and emphasis on fixed assets in organizations led to the reduction of } \\
\text { intert in HRA at the level of organizations and universities }\end{array}$ \\
\hline $\begin{array}{l}\text { Stage 5 } \\
\text { 1981-1990 }\end{array}$ & $\begin{array}{l}\text { Resurgence of international interests in theories and jobs in Human Resources Accounting. } \\
\text { Stage 6 }\end{array}$ \\
$\begin{array}{l}\text { Development of concepts, models, approaches, disclosure, accounting standards and treatment, } \\
\text { generating soft information. }\end{array}$ \\
\hline
\end{tabular}

Source: Flamholtz (1999) and further developed by the author.

The second stage. This stage coincided with the formation of university research teams to develop and evaluate the validity of the historical cost determination model and the value of human resources. In this period, research was conducted to determine the current and future applications of human resource accounting as a tool for managers and financial information users. This means applying research for formulating potential. In early 1967, research team including Likert, Bromet, pile and Flamholtz conducted plans to develop the HRA concepts and methods. The result of this research was published by Bromet and colleagues (1968), the term human resource accounting was used for the first time. They investigated the objections relating to the expense of human cost considering as an asset rather than its calculation.

The third stage. In the 1970s, interest in human resource accounting grew rapidly and involved a lot of academic research throughout the world, while at the same time interest grew at the organizational level... In this period a lot of research into the application of HRA theory within organizations occurred. The American Accounting Association established a committee to oversee the development of human resource accounting (Flamholtz et al. 2002). Several authors reported that human resource accounting had an impact on decision making, including Tomassini (1974) whose findings showed that the HRA data can be effective for management decisions relating to the employees' prioritization at retention and selection of employees. Flamholtz (1979) conducted some research to study the effect of figures related to the value of human resources on official accountants' decisions. The results of this study showed a significant statistical difference between the decisions based on figures calculated on traditional methods of personnel selection, and those figures based on the value of human capital including monetary and non-monetary items. In this period Flamholtz (1971-1972) presented a model based on the premise that the value of an individual is based on the services that he/she will provide to the firm. 
The fourth stage. Starting in 1977 until 1980, some decrease in interests in Human Resources Accounting was noted. Flamholtz and Ansari (1978) proposed the use of HRA as a managerial tool for use in management science... One of the reasons for the reduction of interest in HRA was that the previous preliminary studies that were conducted in relation to HRA were relatively simple while the remaining studies were highly complex. Moreover it became apparent that research into the application of HRA required the interest and cooperation of organizations and also cost money to conduct. Funding expensive research where there was no guarantee of benefit to the organizations meant that organizations were not willing to implement it. (Flamholtz, Bulen, Hua 2002).

The fifth stage. Commencing in 1981 this stage included a revival of interests in the practical application of Human Resources Accounting. The real reason behind this renewed interest was economic development and a transition from a production-driven economy towards a service-oriented economy, and some part of a knowledge-based economy. The application of HRA principles made it possible to understand the importance of human resources for organizations and supported the emergence of intellectual capital over and above physical assets. In this new framework, the future success of the organizations was affected by intellectual capital rather than the physical capital (i.e. total human capital and intangible assets). Before, accounting was unable to respond dynamically to changing conditions because of a fixed focus on static physical assets... In the present era companies need information to come through that can continuously evaluate individuals' skills and abilities. This information providing tools about human capital is the same fundamental aspect of HRA (Flamholtz, Bulen, Hua 2002). Some authors argued that human resource accounting had failed because of a lack of practical use Johanson (1997), however others defended the status of HRA by highlighting a lack of new researchers in this area (Grojer, Johanson 1997). Unfortunately the lack of quantitative results to prove the influence of HRA on decision-making has hindered the establishment of a specific, measurable impact (Roslender, Dyson 1992).

The sixth stage. During this period the focus of human resource accounting changed from measuring human resources and providing hard accounting information, to a method which focuses more on providing soft information (Grojer, Johanson 1997). A recent article concentrates on the use of human resource accounting as a managerial tool. Despite all of the research, there is still no solution to the challenges of the practical application of human resource accounting.

\section{An Analysis of Human Resources Accounting: Definitions and Conceptual Development}

Tracing the historical development of the conceptual and philosophical framework for HRA reflects clearly the development in the definition of this branch of accounting over the years. Interestingly, the Dictionary of Economy (Bucuresti 1999), defines HRA as "all 
human, material, real and monetary elements that can be drawn and used in the production of economic goods to satisfy social needs" (page number required). Professionally, the American Accounting Association (1973) defined HRA as "the process of identifying, measuring and communicating information about human resources in order to facilitate effective management within an organization" (page number required). For the first time recognition and the quantification of human resources for the purpose of assisting the effective management of an organization and to other parties as a key part of the HRA process has been introduced. However it is argued that this definition is unformed as it is not specific as to what constitutes human resources expenditure and how it is to be recognized. From an academic perspective a more specific definition of HRA is the one given by Flamholtz (1974), which refers to HRA as "the process which involves measuring the cost incurred by business firms and other organizations to recruit, select, hire, train and develop human asset" (page number required). For the first time, the relationship between the expenditure on human resources and its role in valuation and reporting has been recognised.

At the corporate level, Woodruff (1973) Vice President of R. G. Batty Corporation, defines HRA as "an attempt to identify and report investments made in human resources of an organization that are presently not accounted for in conventional accounting practice" (page number required). In this definition Woodruff posits that HRA is the systematic accumulation of information about changes in investments made in human resources and reporting back that information to operating managers in order to assist them to make better decisions than they would have been able to make without such additional information. The importance of management decision-making was introduced and a concept of strategic thinking can be seen to emerge.

In terms of revenue generation, Bullen and Eyler (2010), state that HRA involves accounting for expenditure related to human resources as assets, as opposed to traditional accounting, which treats these costs as expenditures that reduce profit. While Ross et al. (1997) states that human capital can simply be explained as the potential of the employees to generate more wealth for organizations in the future. Though it's not owned by the organization, standard human capital management practices determine how well the tacit knowledge of the employees are transferred to the explicit and how well the intellectual capital of the firms are levered so that human capital is transferred to more explicit structural capital. In a similar future-orientated approach, Newman (1999) regards HRA as referring to the measurement of the abilities of all employees of a company, at every level (management, supervisory and ordinary employees) to produce value from their knowledge and the capabilities of their minds. This definition considers the current growth in the service industry where the knowledge and intellectual capabilities of employees are the key to success.

Finally, Friedman and Lev (1974) and Lau and Lau (1978) introduced measurements into HRA by describing it as a method for systematically measuring both the asset value of labour and the amount of asset creation that can be attributed to personnel activities. This 
definition incorporates the economic benefit attributable to human resources in addition to recognizing their cost implication.

By drawing together these various definitions and concepts of HRA, and overlapping them with global trends and economic markers, it is possible to describe the following key characteristics and features of Human Resource Accounting:

1. A definition of the core concept of human resources accounting.

2. The measurement and valuation of human resources.

3. Recording of measurements and valuation in account books.

4. Disclosure of the recorded information in the financial statements.

5. Communication of financial information to decision-making parties, supported by different tools relevant to their decisions.

6. Planning investments in human resources.

7. Planning, controlling and monitoring the changes in operations and the value of human resources.

\section{Challenges of HRA: Concerns from the Profession}

Some professional accountants and researchers (see Gates 2002; Akinsoyinu 1992) argued against HRA with objections that included:

(a) Sensitive Data that is not something that can be shared externally. The main obstacle for reporting human capital externally is that the information reported could be sensitive to the reporting companies and regarded as something that should not be shared externally.

(b) Measurement Not a First Priority for the Company: Companies do not attach first priority to the measurement of human assets; rather they face more urgent issues like human resource requirements and allocation.

(c) Not Enough Time and Resources: This is closely related to the hitherto problem of not attaching priority to the measurement aspect of Human Capital. Where the Human Resource Manager does not give enough importance to the concept of HRA.

(d) Human Resource Professionals Unaware of Value/No clear Return on Investment.

(e) Lack of Clear Guidance and Universal Practice: the lack of a universal approach to its reporting thereby defining the standards that would allow for valuable and meaningful comparisons. There is currently an absence of a universal definition, which does not assist the companies that are proactive enough to measure.

(f) Global and Group Issues: The issue of autonomy in global and group companies poses another problem in the application of HRA. Differences in the valuation of human resources across the countries and overlaid with different levels of salaries or value from the same specific man skills, different measurements and different disclosures may create more complex problems in harmonizing international accounting standards. 
(g) Awareness and Acceptance: The level of awareness and acceptance of HRA is still low as many companies take little initiative to make the information available to shareholders despite having the data available.

(h) Lack of an Industry Standard: The absence of an industry standard means that every company has to evolve its own standard, which can become a tedious process considering that most of them are still involved in improving their business.

(i) Extensiveness of the Research Involved: Another aspect working against the acceptance of HRA is the need for extensive research that it entails. Many companies do not want to go into the intricacies of finding the value of their human resources. While it may be affordable for most big companies to dwell into such best practices, it is likely not going to be an economically viable option for small and medium size companies.

(j) Dynamism of Some Industries: Certain industries, like information technology, are very dynamic due to frequent discoveries and technological advancement. In these types of industries, it is very difficult to predict as to what is going to be the future requirements and how technology is going to shape things in the near future.

\section{Further Limitations of Human Resources Accounting}

There are a lot of other limitations and criticism of HRA. These include the dehumanization of people where they cannot be viewed like physical assets, or where their value might be publicly perceived to be low with serious psychological consequences. Similarly there is a political reason for labour to remain without absolute value as this might generate claims and higher rewards for work with different skill levels. Here it is prudent to question how one amortizes the value of an employee. Does it increase or decrease over time? And in certain industry sectors, the effort to conduct HRA might be questionable amid high staff turnover rates especially in volatile markets. From a process point of view, the lack of a clear-cut procedure in allocating costs and value, the lack of empirical evidence to support its use as a management tool, and some vagueness regarding exactly how the value should be presented in the financial statement all represent significant problems for its wider adoption and use.

Legislatively, it is not clear how tax laws recognize humans as assets, nor is there an accepted method of valuation, confounded further by the abstract, qualitative nature of people where bias might influence objectivity and preciseness that cannot be viewed in monetary terms. These processes and professional practice issues are addressed below.

\section{Human Resource Accounting and International Accounting Standards}

Since the 1960's, HRA has been dominated by two main questions. Firstly, how could human assets be defined as assets on the balance sheet and secondly, can it be valued in 
a satisfactory way? According to International Accounting Standard 38 (IAS 38)) this section covers the treatment of intangible assets. IAS 38 regards intangible assets as non-monetary assets without physical substance which must be identifiable (IASB 2012). In order for an intangible asset to be identifiable it shall be separable and arise from contractual or other legal rights (IASB 2012). However, it shall only be recognized if it is expected to generate future economic benefits and if the cost of the asset can be measured reliably (IASB 2012).

Wyatt (2008) places intangible assets into six specified categories. These include:

1. Technology resource. Contain Research and Development (R\&D) expenditures and related Intellectual property (IP Human resources).

2. Human capital Production resources.

3. Advertising, brands and related IP.

4. Customer loyalty.

5. Competitive advantage.

6. Goodwill.

In order to define an intangible asset, one has to consider different criteria. Each criterion should be identifiable, which means it must be separable from the entity through sale, rent, transfer or exchange and arise from contractual or other legal rights. Also, the entity must control the asset - in this case they have the power to obtain future economic benefits (usually originating in legal rights) (IASB 2012). Future economic benefits can be revenue or cost savings. In order to recognize an intangible asset it must first meet the definition criteria and secondly, meet the recognition criteria (IASB 2012) which are divided in two main parts (IASB 2012):

1. The cost of the asset could be measured reliably.

2. The intangible asset will probably generate future economic benefits to the entity.

In order to assess the future economic benefits, the firm shall use reasonable and supportable assumptions representing the management's best estimate of the economic conditions during the useful life of the asset on the basis of evidence available at the time of initial recognition (IASB 2012).Usually, the cost of an acquired intangible asset can be measured reliable, especially when there is a fee in the form of cash or other monetary assets (IASB 2012). The cost comprises of its purchase price and costs of preparing the asset for use (IASB 2012).

\section{Quantifying Human Resources: Measurement and Valuation Models}

Early HRA research involved the continued development of concepts and models for measurement, valuation and accounting for human resource cost and value, with several models emerging. But each has its own limitations and no one model has proved to be more valid than any other. The table below illustrates the key valuation models and approaches to HRA, where each approach uses different types of methods to determine the value an employee (Dawson 1994). 
1. ECONOMICS MODELS (Value approach):
A. Non-purchased goodwill model (Hermanson model).
B. Competitive bidding model) Hikimian \& Jones).
C. Present value of future earnings model (Lev \& Schwartz model).
D. Economic value model (Pyle and Falmholtz model).
E. Future compensation (rewards) valuation model (Stochastic Model) (Flamholtz model).
F. The relationship between cause, intervention and the end result model (Likert mo- del).
G. The five dimensions model (Mayers \& Flowers model).
H. Present value of net benefits obtained model (Morse model).
I. The discounted net certain benefits model (Ogan model).
J. The methods of adjusted present value (Hermanson model).
$\mathrm{K}$. The changes in value of human resources model (Likert model).

2. MEASUREMENT MODELS ACCORDING TO COST APPROACHES
A. Historical cost model (Flamholtz model).
B. Replacement cost model (Likert and Flamholtz model).
C. Opportunity cost model (Hekimian and Jones model).
D. Government contribution model.

\section{MULTIPLIER METHOD APPROACHES.}

Below is a discussion of some important models:

\section{Historical Cost Approach (Flamholtz model).}

The historic cost method is one of the more popular methods because of its similarities to normal accounting procedures. The model calculates an employee's worth using the total historic costs associated with obtaining and hiring the employee (Dawson 1994). This model is closest to the conventional accounting concept, which derives the costs from transaction data and thus measures the investments in human resources (Brummet et al. 1968). A key factor here is that human resources have to be depreciated when their value declines (Hekimian, Jones 1967). Under this method capital expenditure on human assets are amortized over an expected life of human assets. When an employee is leaving early, any unrecovered expense will be treated as a loss and charged to the profit and losses account. However it is difficult to find out the effective life of human assets and fix the rate at which the cost can be amortized. The actual cost incurred for recruiting, hiring, training and developing those human resources of the firm are divided into Revenue (expense) and Capital (asset) components.

This cost may be classified as follows:

1. Acquisition Cost containing (i) Recruitment Cost (ii) Selection Cost (iii) Placement Cost (iv) Campus Interview Cost. 
2. Training (Development) Cost includes the following costs (i) Formal Training Cost (ii) On the Job Training Cost (iii) Special Training (iv) Development Programs.

3. Welfare Cost include the following costs (i) Medical Expenditure (ii) Canteen Expenditure (iii) Specific and General Allowances (IV) Children Welfare Expenses (v) Other Welfare Expenditure.

4. Other Costs include the following (i) Safety Expenditure (ii) Ex-gratia (iii) Multitrade incentives (iv) Rewarding Suggestions.

This method has the following advantages:

(i) The method is simple to understand and easy to work out.

(ii) The method follows the traditional accounting concept of matching cost with revenue.

(iii) The method can provide a basis for a valuing firm's returns on its investment on human resources.

Also this method suffers from the following limitations:

(i) The method takes into account only a part of the acquisition cost of an employee. It does not consider the aggregate value of their potential services.

(ii) It is difficult to estimate the period over which the human resource will provide service to the organization. It thus creates problems in determining the amount to be amortized over the year,

(iii) The value of human assets according to this method goes on decreasing every year due to amortization.

However, in reality, the value of human assets increases over time on account of people gaining experience.

There are several limitations and dis-advantages to this way of valuing human resources (Rhode et al. 1976):

1. Employees can improve their skills as a result of experiences occurring outside their work. These experiences do not cost the company money and will not be taken in consideration when valuing employees.

2. People who experience the same training will profit differently from this training.

3. Employees can develop patents or processes which are worth far more than the historical costs would imply.

4. An employee can be disturbed by sensitivity training which can harm the company instead of strengthen the company.

5. Another weakness of this model is the possible absence of a connection between the book value of the human assets and the actual or market value (Hekimian, Jones 1967).

6. For this is the difficulty of calculation depreciation. Employees may leave the company sooner or later than expected and grow at different rates (Rhode et al. 1976).

7. It takes into account only acquisition costs and does not take into account his potentiality. 
8. It is not clear when or up to how many years the amount should be amortized.

9. The amount to be amortized is not fixed.

10. Capital cost decreases with amortization.

\section{Replacement cost model (Likert and Flamholtz model).}

This is a measure of the cost to replace a firm's existing human resources. Human resources are to be valued on the assumption that a new similar organization has to be created from scratch and the cost to the firm is calculated if the existing resources were required to be replaced with other persons of equivalent talents and experience. Likert suggests that the cost of an employee should be valued based on what the organization would have to sacrifice to replace an employee if he/she leaves the organization. This includes the cost attributable to the turnover of a present employee, as well as the costs of acquiring and developing a replacement.

The limitations of this approach are described as:

1. There may be no similar replacement for certain existing assets.

2. The replacement value is affected by subjective considerations and therefore the value is likely to differ from one another.

3. It is against conventional accounting practice.

\section{Opportunity cost model (Hekimian and Jones model).}

This model is also known as the "Market Value Method". This is a method of measuring the value of human resources based on the economist's concept of 'opportunity cost', where opportunity cost is the value of an asset when there is an alternative opportunity of using it. In this method there is no opportunity cost for those employees who are not scarce. As such only scarce people should form part of the value of human resources. Opportunity costs are considered as an asset value when the target is for alternative use. Only scarce human resources would have value at any particular point of time. Opportunity cost is calculated on the basis of efforts made by several organizational units, profit centres or departments (Heckiman, Jones 1990).

The limitations of this approach are:

1. The total valuation of human resource on the competitive bid price may be misleading and inaccurate. A person may be a valuable person for the department in which he/she is working and may have a lower price in the bid when viewed by other departments.

2. Only scarce employees are included in this method and as a result other employees may lose their morale, as they are never counted.

3. It would be difficult to identify the alternative use of an employee in an organization.

4. Present Value of discounted future earning Approach (Lav and Schwartz Model):

Developed by Lav and Schwartz (1971) this model the future earnings of various groups of employees are estimated up to the age of their retirement and are discounted at a predetermined rate to obtain the present value of future earnings used in the case of financial assets. It is the present value of future earnings. To determine this value, the organization 
establishes what an employees' future contribution is worth to it today. That contribution can be measured by its cost or by the wages the organization will pay the employee. The organization does not benefit by monitoring the efficiency of its investment in employee development because the investment has little or no impact on the present valuation of future earnings. According to this model, the value of human resources is ascertained as follows:

(i) All employees are classified in specific groups according to their age and skill.

(ii) Average annual earnings are determined for various age ranges.

(iii) The total earnings which each group will get up to retirement age are calculated.

(iv) The total earnings calculated as above are discounted at the rate of cost of capital.

The following formula has been suggested for calculating the value of an employee according to this model.

where:

$$
E\left(V_{y}\right)=\sum_{y=1}^{T} P_{y}(t+1) \sum_{y=1}^{T} \frac{I_{I}}{(1+y)^{t-y}},
$$

$E(V y)$ - expected value for human resource for a person his/her age $Y$ and pension age $T$,

$P_{y}(t)$ - probability of death,

$T$ - time,

$I_{I} \quad$ - expected earning for a person in period $I$,

$Y \quad$ - specified discount rate for a person.

This method has several limitations:

(1) A person's value to an organization is not entirely determined by the salary paid to him/her. A person may like to work for a salary which is less than what he/she actually deserves. Moreover, a salary does not remain constant over a period of time. They tend to change in response to social, political and economic conditions. Hence, they cannot be predicted with precision and accuracy.

(2) The model ignores the possibility that an individual may leave the firm for reasons other than death or retirement. Thus, it overstates an employee's expected service life and his/her future earnings. This model implies that the future work condition of the employee will not change over the span of his/her working life, but will remain the same as at present.

(3) The model does not take into account the changes which people make during their career, from one role to another, at one or more times within the organization itself. This may result in changes in their expected future earnings and ultimately the value of human resources. It ignores the variable of the career movement of the employee within the organization. While an engineer might be an engineer throughout his/her career in the organization this model does not take into account the role changes of employees, where for example a Personnel Manager may become a Chief Legal Officer.

(4) The model also ignores other considerations such as seniority, bargaining capacity, skill experience, etc., which may result in the payment of higher or lower salaries to 
employees. Thus, the salaries paid to employees may not really represent the employee's real worth to the organization.

(5) This method does not give the correct value of human assets as it does not measure their contributions to achieving organizational effectiveness (Scarpello 1989).

\section{Future rewards valuation model (Stochastic Model) (Flamholtz model).}

This model has been suggested by Flamholtz (1971). This is an improvement on the 'present value of future earnings model' since it takes into consideration the possibility or probability or an employee's movement from one role to another in his/her career and also of his/her leaving the firm earlier than his/her death or retirement. According to this model, the ultimate measure of an individual's value to an organization is his/her expected realizable value. Expected realizable value is based on the assumption that there is no direct relationship between costs incurred on an individual and his/her value to the organization at a particular point of time. An individual's value to the organization can be defined as the present worth of a set of future services that are expected to be provided during the period he/she remains in the organization.

The model suggests a five step approach for this purpose.

1. Determination of the period for which a person is expected to serve the organization.

2. Identification of service states (i.e. roles or posts) that the employee might occupy during his service career including the possibility of him/her leaving the organization.

3. Estimation of the probable period for which a person will occupy each possible service state (i.e. posts or roles) in future in the organization.

4. Estimation of the value derived by the firm when a person occupies a particular position.

5. The total value of the services derived by the organization by different employees or group of employees is determined. The value thus arrived at is discounted at a predetermined rate to get the present value of human resources.

This model formulated in this equation:

where:

$$
E(R V)=\sum_{i=1}^{n}\left[\sum_{i=1}^{m} \frac{R i-P(r i)}{(1+R)^{k}}\right],
$$

$R i \quad$ - value of $R$ group of human resource,

$P(R i)$ - probability that a person will occupy specific statues,

$n \quad-$ case of leaving work,

$R \quad-$ relevant discount rate.

The limitations of this model are that it that suffers from nearly all the same drawbacks as the present value of future earnings models... In addition, it is difficult to obtain reliable data for determining the value derived by the firm during the period a person occupies a particular position. The model also ignores the fact that individuals operating in a group 
may have a higher value for the organization as compared to individuals working independently.

\section{Present value of net benefits obtained model (Morse model).}

This model has been suggested by Morse (1973). According to this model, the value of human resources is equivalent to the present value of net benefits derived by the firm from the service of its employees.

where:

$$
\boldsymbol{A}=\sum_{i-}^{N}=\int_{y}^{N} \frac{I_{i(t)}}{(1+r)^{t-\gamma}} d t+\int_{\gamma}^{T} \frac{X_{(t)}}{(1+r)^{t-\gamma}} d t,
$$

A - value of human assets to a formal organization,

$N$ - number of individuals currently employed by the organization,

$y$ - current time,

$T$ - highest time at which an individual currently employed leaves the organization,

$I_{i(t)}$ - net value of the services rendered by an individual $i$ at time $t$ to the organization,

$R$ - time value of money.

The method involves the following steps.

1. The gross value of services to be rendered in future by the employees in their individual as well as their collective capacity is determined.

2. The value of future payments (both direct and indirect) to the employees is determined.

3. The excess of the value of future human resources over the value of future payments is ascertained.

4. The present value of the net benefit is determined by applying a pre-determined discount rate (generally the cost of capital). This amount represents the value of human resources to the organization.

\section{Certainty Equivalent of Net Benefit Model (Ogan model).}

This model was suggested by Pekin Ogan (1976). This is essentially an extension of the "net benefit approach" as suggested by Morse. According to this approach, the certainty with which the net benefits in future will accrue should also be taken into account, while determining the value of human resources. The approach requires the determination of the following:

1. Net benefit from each employee as explained under 'net benefit approach'.

2. Certainty factor at which the benefits will be available.

3. The net benefits from all employees multiplied by their certainty factor will give certainty equivalent net benefits. This will be the value of human resources of the organization. 
where:

$$
K_{k j}=\left[\sum_{i=1}^{n} \sum_{k=t}^{l-t} \frac{1}{(1+r)^{k}}\right] \times V_{a j},
$$

$K_{k j}$ - total adjusted net present values of human resources in a Professional service organization,

$L$ - finishing the time of an existing person in the firm,

$I$ - chain of existing the worker in the job $1,2,3, \ldots, n$,

$V_{a j}$ - net certain benefits created from the existing human resource in the firm.

Accountants differ among themselves when it comes to accounting treatments and investment in human resources. They also differ in the types of disclosure in the financial reports. Two distinct trends in thinking are evident. Firstly, the traditional point of view supports accountants in addressing the costs of investment in human resources earning expenditures, and they disclose it in financial reports as an expense. This approach is defended by accountants for the following reasons:

1. Adherence to conservative accounting principles which rejects any accounting procedures that increase profits or increase assets. This inhibits the acceptance of viewing investments in human resources as assets because it will have the effect of increasing profits in the short term versus expected losses in the future if any human resources left the firm.

2. Human resources may have value from the point of entity view, but may not be have any market value if the unit has decided to dispense from the work.

3. The expansion of the disclosure to include the disclosure of investment in human resources may lead to the achievement of benefits to the firm, but at same time the expansion of the disclosure will be at a high costs which may exceed the benefits expected by it.

4. Other reasons that inhibit valuing human resources as assets relate to the survival of the human resources function in a firm because if their functional performance is calculated as costing the organization money, their continued existence inside the firm will be compromised.

The above reasons and arguments prompted some accountants to block the acceptance of the idea of addressing the investment costs in human resources and disclosed as assets. But the outlook has changed to include the provision of potential future economic benefits of economic unity. Moreover with increasing acknowledgement of the importance of HR capabilities that enable them to acquire and maintain tangible assets that help achieve the goals of the firm, the recent trend of accountants have adopted a more contemporary view of accounting. This adoption refers to treating investment in human resources costs as one element of assets elements and disclosed in the financial reports. Supporters of this trend argue that human resources is one of the most important resources available to the unit, and 
as long as the human resource produces goods and provide services that we can measure its costs, there is no reasons to prevent accountants from measuring HR value and cost. They can also disclose it as assets to support the interests of the various stakeholder parties within the firm. Some others recognize that human resources represent economic benefits to the firm that are reflected in increasing production, profitability, growth and competitiveness. Considering human resources cost as expenses rather than assets, means cancelling out any future economic benefits. In this context, some may criticize the level of uncertainty about the contribution of HR in achieving future economic benefits for the firm. This criticism can be analysed by using a real life case study involving a sports club, where players contribute directly to the success of football and thereby enable the club to continue operating. Thus they contribute directly to the achievement of future economic benefits for the club. Players sign a legally binding contract with the club which gives the club legal rights to retain their services. In addition players can only leave the club or play for another one only after obtaining approval from the mother club. Another reason underpinning a growing contemporary trend in HRA is the increasing technological complexity of a modern business environment, and the increase in time required for human resources to gain experience. In some way it can be regarded as a barrier to entry and will make human resources realize the importance of the integrity of resources in the long term. Carper (2000:4) recognizes how business acquisitions are being made on the basis of the target company's human resource skill level amongst managers, engineers and IT specialists, not on the physical plant or equipment. Finally the contemporary trend towards matching expenses and revenues for the same financial year is predicated in the belief that expenses underpinning the revenues and the investment costs in human resources contribute to achieving revenues for several years and not one year. Logically then, human resources should be treated as assets, where yearly efforts are represented by costs amortized over several years. In addition the principle of disclosure of useful information should be made available for planning, controlling and performance evaluation. For example Professor Chakraborty has suggested that 'human assets' should be shown under the heading of Investments in the Balance Sheet of an organization. He has not favoured its position under the heading 'fixed assets' since it would cause a problem of depreciation, capital gains and losses, in the event of the human resource exit. Similarly, he has not favoured their inclusion in current assets on the ground that this will not be consistent with the general meaning of the term.

\section{Suggested model: Historical cost adjusted with discounted present value of extra non-ordinary earnings.}

As number of models have been developed to value human assets. In addition, there are two types of expenditures that could be set:

(1) Capital Expenditure: Acquisition, Development, Retention, Update or up-grading and Hiring cost, Recruitment \& Training cost. 
(2) Revenue Expenditure: Wages, Salaries, Bonus, Commission, prerequisites, allowances and short term motivation and efficiency maintenance cost. Also there are expected benefits that the entity may earn from acquiring these human resources that exceed normal earning, or compared to non-acquiring this employee or in comparison with other entities.

The proposed calculation of future capital expenditure did not take into consideration the initial cost that would be amortized over the years. Also previous models did not take in account the probability of two important factors:

1. The probability of resigning, accidents or death.

2. The probability of getting benefit from acquiring specified extra benefits from spending on this human asset.

Given the previous attempts at developing an HRA model it is clear that it is not an easy task. Even highly developed models such as the Stochastic model have limitations it is yet to overcome. It is also important that a model is based on a measure for which enough data is available. For example the reliable and verifiable cost information beside the predicted data for future benefits has to be determined via reliable and accurate methods, and in addition the correlation between the measure and the value of human resources has to be strong. The business environment also has to be more sympathetic to human resource accounting. It is important that more research is done about the net benefit of human resource accounting and also about practical application in selecting the right measures.

The proposed model is built on an assumption of merging the initial historical cost of human resources (as explained previously) and the expected, extra non-ordinary future benefits from acquiring this specified human resource asset, discounted with a proper discount rate, while taking into consideration the probable likelihood of achieving this change of earning or benefit. To satisfy the needs of conservative accounting policies and to include a matching principle between earnings and cost in same financial year, the model also focuses on the probability of that person leaving the firm or resigning or dying.

The model could be formulated as:

$$
H R \times E(V)=\sum C\left(q_{z}\right)+\left[P\left(\pi_{t x}, \pi_{t n}\right) \times \sum_{i=1}^{t}\left(\frac{\pi_{t x}-\pi_{t n}}{(1+r)^{t}}\right)\right] \times p(\varepsilon),
$$

where:

$H R \times E(V)-$ is the expected value of a human resource at the point of acquisition,

$\Sigma C\left(q_{z}\right)=\left(q_{1}+q_{2}+q_{3}+\ldots+q_{n}\right)-$ are the historical cost functions,

$P\left(\pi_{t x}, \pi_{t n}\right) \quad$ - is the probability of attending the amount of extra-ordinary earning or net benefits,

$\pi_{t x} \quad-$ is the amount of extra ordinary benefits or earnings correlated with the existing specified $H R$,

$\pi_{t n} \quad-$ is the amount of ordinary benefits or earnings correlated with the absence of the specified HR, 
$P(\varepsilon) \quad-$ is the probability of death, accident or resigning from the job,

$t \quad-$ the time line of contract,

$r \quad-$ discount rate for year $\mathrm{t}$.

Any future capital expenditure requires a re-evaluation of human assets in order to recalculate the amortization amount for the following years. The amortization amount per year will then be calculated according to the equation

$$
\operatorname{Amor}_{t}=\frac{H R \times E(V)}{N},
$$

where:

$$
\begin{aligned}
& \text { Amor }_{t} \text { - amortization for the year } t, \\
& N \quad \text { - years of contract. }
\end{aligned}
$$

This amount of amortization closed yearly in profit and losses accounts for the matching of the earnings recognized by certain HR assets.

\section{Conclusions}

1. Failure to recognize the value of HR in financial statements has led to a number of misleading results such as (i) Reducing the value of assets where potential investors will certainly want to know the value of human resources in the organization, and where analysts want to calculate the best investment returns if it has all the accounting assets to hand, including human capital, (ii) Reducing the value of income, as enormous expenditures of recruitment, training and human resources development, will inevitably reduce the income.

2. It is important to ensure the availability of criteria necessary for the recognition of human resources as an asset. To recognize human resources as assets in the financial statements of financial positions, depend on the definition of asset, which is an economic resource controlled by an entity as a result of a previous transaction, and the criteria of recognition related to the probability of inflow benefits from the assets to the entity, and the possibility of the reliable measurement of these benefits.

3. There are several models and approaches that measure the value of HR and suggest how to disclose it in financial statements. Though different models and methods have already been proposed for HRA, it is still extremely difficult to determine the actual value of the human resources of a firm. The non-recognition of human resources as assets creates difficulties and limitations of using and applying previous models and approaches, leading to the low levels of credibility of each model and its ability to reflect the value of human resources logically and reasonably.

4. This paper suggests a model that would overcome some of the problems inherent in the previously discussed models by taking into consideration the current benefits and future 
benefits from human resources and distributing it over the years of an employment contract. The proposed module for the measurement of human resources also contributes to, estimated employees' benefits that are included in the budget when acquiring a human resource, which are calculated for continuous years for budgeting purposes.

\section{References}

Alfredson K., Leo K., Picker R., Loftus J., Clark K., Wise V. (2009), Applying international financial reporting standards, $2^{\text {nd }}$ ed., Australia: John Wiley \& Sons Australia, Ltd.

American Accounting Association's Committee on Human Resource Accounting (1973), Report of the Commit on Human Resource Accounting. The Accounting Review, 48 (Supplement): pp. 169-185.

Barako D.G., Hancock P., Izan H.Y. (2006), Factors influencing voluntary corporate disclosure by Kenyan companies, "Corporate Governance" vol. 14, no. 2, pp. 107-125.

Brummet R.L., Flamholtz E.G., Pyle W.C. (1968), Human resource measurement -A challenge for accountants, "The Accounting Review" vol. 43, no. 2, pp. 217-224.

Brummet R.L. (1970), Accounting for Human Resources, “Journal of Accountancy” vol. 130, no. 6.

Chow C.W., Wong-Boren A. (1987), Voluntary financial disclosure by Mexican corporations, "The Accounting Review"vol. 62, no. 3, pp. 533-541.

Clacher I. (2010), National accounting for intangible assets in the knowledge economy, "Journal of Financial Regulation and Compliance" vol. 18, no. 2, pp. 106-119.

Cooke T.E. (1989), Voluntary corporate disclosure by Swedish companies, "Journal of International Financial Management and Accounting" vol. 1, no. 2, pp. 171-195.

Coff R., Flamholtz E., Searfoss G. (1988), Developing Human Resource Accounting as a Human Resource Decision Support System, "Accounting Horizons" vol. 2, no. 3.

Dawson C. (1994), The Use of a Simulation Methodology to Explore Human Resource accounting, "Management Decision" vol. 32, no. 7.

Doane D.P., Seward L E. (2011), Applied statistics in business and economics, $3^{\text {rd }}$ ed., Boston: McGraw-Hill/Irwin.

Financial Accounting Standards Board (FASB) (2001), Improving business reporting: Insights into enhancing voluntary disclosures, Steering Committee Report, Business Reporting Research Project. Norwalk, CT: FASB.

Flamholtz E.G. (1971), A model for human resource valuation: A stochastic process with service rewards, "The Accounting Review", vol. 46, no. 2, pp. 253-267.

Flamholtz E.G. (1985), Human resource accounting, San Francisco: Jossey-Bass Publishers.

Flamholtz E. (1972), Toward a Theory of Human Resource Value in Formal Organizations, "Accounting Review" vol. 47 , no. 4 .

Flamholtz E. (2005), Conceptualizing and Measuring The Economic Value of Human Capital, "Journal of Human Resource Costing \&Accounting" vol. 9, no. 2.

Flamholtz E. (1974), Human Resource accounting: A Review of Theory and Research, "Journal of Management Studies" vol. 11, no. 1 .

Flamholtz E. (1972), Human Resource accounting: A Review of Theory and Research, "Academy of Management Proceedings".

Grojer J, and J. (1991), Human costing resource and accounting. Stockholm university.

Hansen B. (2007), Personnel investments and abnormal return, "Journal of Human Resource Costing and Accounting” vol. 2, no. 2, pp. 9-29.

Hermanson R.H. (1986), Accounting for human assets. Research monograph no. 99. Atlanta, Georgia: Business Publishing Division, College of Business Administration, Georgia State University.

Hidalgo R., Garcia-Meca E., Martinez I. (2011), Corporate governance and intellectual capital disclosure, "Journal of Business Ethics" vol. 100, no. 3, pp. 483-495.

International Accounting Standards Board (IASB) (2015), The conceptual framework for financial reporting, London: IFRS Foundation.

Likert R.M. (1967), The human organization: Its management and value. New York: McGraw-Hill Book Company.

Lev B., Schwartz A. (1971), On the Use of the Economic Concept of Human Capital in Financial Statements, "Accounting Review" vol. 46, no. 1. 
Likert R., Pyle W. (1971), A Human Organizational Measurement Approach, "Financial Analysts Journal” vol. 27, no. 1 .

Myers S., Flowers V. (1974), A Framework for Measuring Human Assets, "California Management Review” vol. 16, no. 4.

Ogan P. (1976), A Human Resource Value Model for Professional Service Organizations, "Accounting Review" vol. 51, no. 2 .

Porwal L.S. (1993), Accounting theory, New Delhi: Tata McGraw-Hill Publishing Co., New Delhi Press.

Robbins W.A., Austin K.R. (1986), Disclosure quality in governmental financial reports: An assessment of the appropriateness of a compound measure, "Journal of Accounting Research" vol. 24, no. 2, pp. 412-421.

Robinson D. (1975), Two Approaches to Human Accounting, "Accountancy" February.

Sackman S.A., Flamholtz E.G., Bullen M.L. (1989), Human resource accounting: A state-of-the-art review, "Journal of Accounting Literature" vol. 8, pp. 235-264.

Williams S.M. (2001), Is intellectual capital performance and disclosure practices related?, "Journal of Intellectual Capital" vol. 2, no. 3, pp. 192-203.

\section{KSIĘGOWE ZASOBY LUDZKIE: SUGEROWANY MODEL POMIARU I WYCENY}

Streszczenie: Transformacja gospodarcza, jaka dokonała się w skali globalnej, z gospodarek opartych na produkcji poprzez gospodarki oparte na usługach, do gospodarek opartych na wiedzy, oznacza dla firm większą koncentrację na zasobie, jakim są ich pracownicy. Dzieje się tak z uwagi na globalne niedobory umiejętności, jak również możliwość utraty cennej wiedzy wewnętrznej w konsekwencji odejścia pracownika z firmy. Pracownicy organizacji, uznani przez ekonomistów za najważniejszy jej zasób, ponieważ kontrolują i zarządzają innymi zasobami, przyczyniają się w bezpośredni sposób do jej sukcesu lub niepowodzenia. Z uwagi na ogromne znaczenie tego zasobu, coraz większe zainteresowanie zyskuje rachunkowość zasobów ludzkich, w której proponuje się wiele modeli i technik do wyceny zasobów ludzkich w szerszym kontekście. Mimo solidnych badań, nadal toczą się ożywione dyskusje o tym, czy należy ujmować zasoby ludzkie w sprawozdaniu finansowym czy też nie. Historycznie rzecz biorąc, rachunkowość nie uznawała zasobów ludzkich za składnik aktywów w sprawozdaniu z sytuacji finansowej z uwagi na brak odpowiednich wskaźników mających zastosowanie do pracowników, a także ze względu na brak odpowiednich modeli przypisywania wartości zasobom ludzkim. Oczywiste jest zatem, że w momencie silnej orientacji na kapitał ludzki luka wiedzy tego rodzaju rodzi wiele pytań wobec praktyki rachunkowości. Rachunkowość zasobów ludzkich ma możliwości wypracowania alternatywnego rozwiązania przydatnego zarządom w procesie decyzyjnym, zwłaszcza w zakresie adekwatności zasobów ludzkich z punktu widzenia kondycji finansowej. Do tej pory istnieje jednak potrzeba dalszego ustalenia wiarygodnej platformy rachunkowości zasobów ludzkich, w szczególności drogą uzyskania solidnych wyników badań jakościowych. W związku z tym niniejszy artykuł dokonuje dalszej analizy możliwości włączenia zasobów ludzkich do kategorii aktywów, określa rodzaje wydatków wymaganych w sprawozdaniach finansowych i proponuje rodzaje ujawnień niezbędnych do przedstawienia aktywów w postaci zasobów ludzkich. W szczególności, niniejszy artykuł proponuje model wyceny pozbawiony ograniczeń poprzednich modeli i przedstawia obliczenia, które organizacja można wykorzystać, decydując się na uwzględnienie tych zasobów w sprawozdaniu finansowym. Dodatkowym wynikiem tego artykułu jest doprecyzowanie definicji pojęcia rachunkowości zasobów ludzkich jako podzbioru ogólnej rachunkowości z punktu widzenia Międzynarodowych Standardów Sprawozdawczości Finansowej (MSSF) i mającego zastosowanie do MSR 38 w zakresie sprawozdawczości finansowej z 2015 roku.

Sowa kluczowe: rachunkowość zasobów ludzkich, MSR 38, model Flamholtza, model Leva i Schwartza

\section{Citation}

Arkan.T. (2016). Human Resources Accounting: A Suggested Model for Measurement and Valuation. Finanse, Rynki Finansowe, Ubezpieczenia, 1 (79), 173-193; www.wneiz.pl/frfu. 